\title{
Meat quality of Santa Inês sheep raised in confinement with diet containing cactus pear replacing corn
}

\section{Roberto Germano Costa ${ }^{1}$, Tiago Ferreira Pinto ${ }^{2}$, Geovergue Rodrigues de Medeiros ${ }^{2}$, Ariosvaldo Nunes de Medeiros ${ }^{1}$, Rita de Cássia Ramos do Egypto Queiroga ${ }^{1}$, Israel Hernandez Treviño ${ }^{3}$}

\footnotetext{
1 Universidade Federal da Paraíba. Programa de Doutorado Integrado em Zootecnia, 58396-000, Areia-PB - Brasil.

2 Instituto Nacinonal do Semiárido - Insa/MCT, Campina Grande -PB - Brasil.

3 Universidade de Puebla - México.
}

\begin{abstract}
The objective of this study was to assess the tissue component yields and the physical, chemical and sensory characteristics of meat from Santa Inês sheep fed diets in which cactus pear partially or completely replaced corn. The study used 45 Santa Inês rams with initial live weight of $25 \pm 2.5 \mathrm{~kg}$ and final weight of $35 \pm 1.5 \mathrm{~kg}$ in a completely randomized design with five treatments $(0,25,50,75$ and $100 \%)$ and nine replicates per treatment. The leg of the animal was used to analyze the tissue component yields, and the longissimus dorsi muscle was used for assessment of the sensory characteristics and the physical and chemical compositions. The inclusion of cactus pear in the diet increased the adipose tissue percentage quadratically, up to $50 \%$, reducing the muscle/fat ratio. The lipid content of the meat decreased with the inclusion of cactus pear in the diet. The results indicate that cactus pear can replace $100 \%$ of the corn in the diets of Santa Inês sheep kept in confinement, resulting in a decreased lipid percentage and without compromising the physical and sensory characteristics of the meat.
\end{abstract}

Key Words: meat tenderness, Opuntia ficus indica, proximate composition, sensory characteristics

\section{Introduction}

The growing global demand for sheep meat, coupled with consumer demands for higher quality meat with lower lipid and cholesterol contents (Schönfeldt \& Gibson, 2008), has attracted interest from academic researchers and industry with the aim of producing a standardized product that meets these demands.

In the semi-arid region of Brazil, the staple food of ruminants derives from the Caatinga vegetation, which is influenced by the season characteristic of the region. During the dry season, the quality of forage is significantly reduced and characterized by cell wall lignification and low crude protein content. Cactus pear (Opuntia ficus indica MILL) is well adapted to the soil and climate of this region and thus, has the potential to substitute corn, which has a high cost due to competition for the feeding of poultry, pigs and humans. As forage, cactus pear has low dry matter (DM), a low crude protein percentage and a high concentration of non-fibrous carbohydrates and neutral detergent-soluble fibers (Wanderley et al., 2002). The percentage of starch is high in relation to other forages, varying from 12 to $18 \%$ (Retamal et al., 1987), providing water, energy, minerals and vitamin A to herds, especially during the dry season.
According to Huidobro \& Cañeque (1994), the economic value of livestock animals is essentially determined by the tissue composition, the yield of the parts and the chemical composition of the meat. Meat quality can be assessed based on the nutritional and hygienic profile, ease of use and handling and product presentation. To determine the factors that influence these qualities, research has utilized chemical, physical and sensory tests that assess the characteristics perceived by the consumer at the time of purchase or consumption (Sañudo, 1992).

The most important physical properties of meat are temperature, $\mathrm{pH}$, color, tenderness and weight loss by cooking (Dabés, 2001). From these, pH is the most relevant factor, as it influences water retention capacity and weight loss by cooking and shear force (Bressan et al., 2001). According to Devine et al. (1993), pH also influences the tenderness, succulence, flavor, aroma and color of meat. Decreases in $\mathrm{pH}$ and temperature during the process of rigor mortis directly influence the meat quality. Color is the most important characteristic for the consumer at the time of purchase, and it reflects the chemical state and myoglobin content in the muscle. Color is also influenced by $\mathrm{pH}$ and the post mortem glycolysis rate. 
The purpose of this study was to assess the tissue component yields and the physical, chemical and sensory characteristics of meat from Santa Inês sheep fed diets in which cactus pear partially or completely substituted corn.

\section{Material and Methods}

The experiment was conducted at the Small Ruminant Research Unit of the Agricultural Sciences Center at Universidade Federal da Paraíba, located in the municipality of São João do Cariri, Paraíba, in the Cariri Oriental microregion of Brazil. The experimental area is located at coordinates $7^{\circ} 23^{\prime} 27^{\prime \prime} \mathrm{S}$ and $36^{\circ} 31^{\prime} 58^{\prime \prime} \mathrm{W}$. The local climate is classified as Bsh (hot semi-arid) according to the Köppen climate classification system.

Forty-five Santa Inês rams with an average weight of $25 \pm 2.5 \mathrm{~kg}$ were used in the study. The animals were kept in individual stalls with packed dirt flooring, provided with food and water troughs and were given the experimental diets. The animals were weighed, identified, treated for ecto- and endoparasites and vaccinated against clostridiosis. Animals were weighed every seven days, from the start of the experiment until slaughter.

The feed consisted of the following: Tifton hay (Cynodum sp), soybean meal, corn meal, wheat meal, calcium carbonate, sodium bicarbonate and cactus pear. The diets (Table 1) were formulated to meet the requirements of sheep with a live weight of $25 \mathrm{~kg}$ and a daily gain of $250 \mathrm{~g} /$ day (NRC, 1985). The treatments consisted of increasing levels of cactus pear substitution of corn: 0, 25, 50, 75\% and 100\%. The experimental feeds were completely mixed in order to induce higher consumption by the animals and were given twice a day. The total DM intake was determined by the daily amounts of feed supplied and rejected, and feed was supplied to ensure approximately $10 \%$ leftovers.

When the animals reached a live weight of $35 \pm 2.3 \mathrm{~kg}$, they were given a liquid diet (solid fasting) for a period of 12 hours before slaughter. The slaughter method used was stunning at the atlanto-occipital region, followed by bleeding, skinning and evisceration. The carcasses were identified by animal and treatment, and the values for $\mathrm{pH}$, temperature and color of the semimembranosus muscle (on the left leg) were determined before refrigeration (time 0 ). The carcasses were subsequently transported to cold storage, where they remained for 24 hours at $4{ }^{\circ} \mathrm{C}$, hanging from the Achilles tendon by hooks $14 \mathrm{~cm}$ apart from each other.

The $\mathrm{pH}$, color and temperature measurements of the semimenbranosus muscle were taken 45 minutes and 24 hours after slaughter. A Testo 205 portable $\mathrm{pH}$ meter was used to measure $\mathrm{pH}$ and temperature, using the methodology described in AOAC (2000). Meat color was measured using a Minolta CR-200 calorimeter, which measures luminosity, red and yellow contents, respectively.

Legs were stored in plastic bags, according to the methodology described by Silva Sobrinho (1999), for quantitative and qualitative analyses of meat. Legs were then dissected for assessment of tissue composition, and the following groups of tissue were separated: fat, muscle,

Table 1 - Ingredients in diets and feed composition for different levels of replacement of corn by cactus pear

\begin{tabular}{|c|c|c|c|c|c|}
\hline \multirow[t]{2}{*}{ Ingredients ( $\mathrm{g} / \mathrm{kg}$ of natural matter) } & \multicolumn{5}{|c|}{ Replacement level (\%) } \\
\hline & 0 & 25 & 50 & 75 & 100 \\
\hline Cactus pear & 0.0 & 70.0 & 140.0 & 210.0 & 280.0 \\
\hline Soybean meal & 176.0 & 176.0 & 176.0 & 176.0 & 176.0 \\
\hline Wheat meal & 114.0 & 114.0 & 114.0 & 114.0 & 114.0 \\
\hline Tifton hay & 400.0 & 400.0 & 400.0 & 400.0 & 400.0 \\
\hline Mineral & 15.0 & 15.0 & 15.0 & 15.0 & 15.0 \\
\hline \multicolumn{6}{|l|}{ Feed composition ( $\mathrm{g} / \mathrm{kg}$ ) } \\
\hline Dry matter & 894.6 & 593.4 & 444 & 354.6 & 295.2 \\
\hline Organic matter & 907.2 & 899.3 & 891.4 & 883.5 & 875.6 \\
\hline Mineral matter & 51.1 & 58.4 & 65.6 & 72.8 & 80.00 \\
\hline Crude protein & 162.4 & 159.1 & 155.7 & 152.3 & 148.9 \\
\hline Ether extract & 23.8 & 22.5 & 21.1 & 19.8 & 18.5 \\
\hline Non-Fibrous carbohydrates & 379.4 & 361.5 & 343.9 & 326.2 & 308.4 \\
\hline Total digestible nutrients ${ }^{1}$ & 638.8 & 621.5 & 604.2 & 586.9 & 569.5 \\
\hline Metabolizable energy (Mcal/kg DM) & 2.30 & 2.24 & 2.18 & 2.12 & 2.05 \\
\hline
\end{tabular}


bone and remaining tissue. After separating the tissue, five muscles that cover the leg (adductor, semitendinosus, semimembranosus, biceps femoris and quadriceps) were weighed. The length of the femur was measured to obtain the muscularity index of the leg, using the formula described by Purchas et al. (1991):

$[\mathrm{MIP}=\sqrt{ }(5 \mathrm{M} \mathrm{WT} / \mathrm{FC}) / \mathrm{FC}]$, where: MIP = muscularity index of the leg; $5 \mathrm{M} \mathrm{WT}=5$ muscle weight (biceps, quadriceps, semitendinosus, semimembranosus and adductor); FC = femur circumference.

Samples of longissimus muscle were packed and stored in a freezer at $-20^{\circ} \mathrm{C}$ for 30 days for the following analyses: proximate chemical composition (ash, moisture, protein, lipids), physical composition (weight loss by cooking, shear force) and sensory analysis. All physical and chemical analyses were done in duplicate, using methodology adapted from Madruga et al. (2001).

The moisture, ash and protein contents were determined according to the AOAC (2000), using methods 985.41, 920.153 and 928.08, respectively.

The total lipids were measured according to the methodology described by Folch et al. (1957). Thirty milliliters of a chloroform-methanol (2:1 v/v) mixture were added to $2 \mathrm{~g}$ of weighed sample. The mixture was stirred for 2 minutes using a Biomatic vortex, and then filtered using qualitative filter paper. After filtration, the wall of the vial containing the sample was washed with $10 \mathrm{~mL}$ of the solvent mixture, which was subsequently filtered and added to the first filtrate. The final volume was recorded.

Sodium sulfate at $1.5 \%$ level was added to a $20 \%$ volume of the final filtrate. After the mixture was stirred and the phases were allowed to separate, $5 \mathrm{~mL}$ from the bottom phase were removed and transferred to a previously weighed beaker. The beaker was placed in a $105^{\circ} \mathrm{C}$ oven until the solvent mixture evaporated. It was then left to cool in a desiccator and weighed along with the fat residue.

The weight loss due to cooking was determined following the procedure described by Duckett et al. (1998a). The samples, composed of three slices of approximately $2.5 \mathrm{~cm}$ in length, were weighed, placed in a container covered with aluminum foil and baked in a pre-heated oven to $170{ }^{\circ} \mathrm{C}$ until the core temperature reached $70^{\circ} \mathrm{C}$. Core temperature was measured using a copper-constantan thermocouple equipped with a digital reader (Delta OHM, model HD9218, Italy). Samples were subsequently cooled to room temperature and re-weighed. The losses due to cooking were calculated using the differences in weight before and after heat treatment and are expressed as percentages (g/100 g).
For texture evaluation, shear force was measured using the methodology described by Duckett et al. (1998b). The samples used were the same as those used for analysis of weight loss due to cooking. After cooking and weighing, two cylinders were removed from each meat slice in the direction of the fiber, using a cylindrical hollow punch of $1.6 \mathrm{~cm}$ in diameter. Cylinders were cut transversely using a TA-XT2 texturometer (Surrey, England) equipped with a Warner Bratzler blade, which was operated at $20 \mathrm{~cm} / \mathrm{min}$. The peak shear force was recorded and expressed as Kgf $/ \mathrm{cm}^{2}$.

Samples from the longissimus dorsi muscle were used for the sensory analysis of the meat. The samples were defrosted in a refrigerator for 12 hours, separated by treatment and cut into 2.5 -cm cubes. Meat cubes underwent a dry cooking process in an electric grill for approximately 8 minutes ( 4 minutes for the upper portion and 4 minutes for the lower portion), without the addition of salt or condiments. Samples were cooked as the tasters arrived for the test. The panel consisted of eleven trained tasters, using non-structured 9-cm scales used to indicate the intensity of sensory characteristics (varying from the least favorable condition to the most favorable; Figure 1). There were three replicate rounds per sample group, and each replicate included five samples representing the five different experimental treatments, in accordance with the methodologies described by Amarine et al. (1965), Larmond (1979) and Madruga et al. (2000).

The experimental design was completely randomized, with five treatments and nine replicates per treatment. In addition to analysis of variance, regression analyses were also performed for each of the experimental replacement levels of corn by cactus pear. Statistical analyses were conducted using the computer program SAEG (version 9.1).

\section{Results and Discussion}

The replacement of corn by cactus pear influenced the percentage of fat in the legs of sheep quadratically $(\mathrm{P}<0.05)$, reaching a maximum level of $7.61 \%$, which corresponds to a $44.53 \%$ replacement level. According to Fernandes et al. (2010), however, there is still no minimum value for fat thickness in sheep that can be used to determine an excess or reduction of fat deposition. In contrast to the effect on fat, the replacement of corn by cactus pear did not affect the percentage of muscle and bone $(\mathrm{P}>0.05)$. The changes in the yield of adipose tissue related to diet are directly associated with energy supply, but they may also be influenced by breed or age.

The muscle/fat ratio was affected quadratically $(\mathrm{P}<0.05)$, reflecting the quadratic effect on the percentage of fat. The 
muscularity index of the leg was not influenced $(\mathrm{P}>0.05)$ by the inclusion of cactus pear in the diet. The mean muscularity index value observed was $0.36 \mathrm{~kg} / \mathrm{cm}$ (Table 2), which is similar to previously reported values for the Santa Inês breed and indicates good muscle conditions of the animals in the study. Silva Sobrinho et al. (2005) reported mean values of $0.42 \mathrm{~g} / \mathrm{cm}$ in a study of crossbred Ile de France $\times$ Ideal lambs, showing the potential of the Santa Inês breed relative to other breeds developed for meat production.

Substituting corn with cactus pear had no effect $(\mathrm{P}>0.05)$ on the initial and final pHs of the carcasses, and the rates of $\mathrm{pH}$ decrease after slaughter and the final $\mathrm{pH}$ values varied. While final $\mathrm{pH}$ values are typically below 5.8 (Hoffman et al., 2003; Silva Sobrinho et al., 2005), the final $\mathrm{pH}$ values for all of the treatments in this study were below 5.8 (average of 5.68), indicating a desirable increase in the activity of calpains and cathepsins, which contribute to the softening of meats (Teixeira et al., 2005).

The values of luminosity, and colors red and yellow were not affected $(\mathrm{P}>0.05)$ by the incorporation of cactus pear into the diet. Higher values indicate increased color intensity or tonality. These tonalities reflect the amount of myoglobin and the relative proportions of this pigment, which can be found in several forms: reduced myoglobin
( $\mathrm{Mb}$, purple color), oxymyoglobin ( $\mathrm{MbO}_{2}$, red color) and metamyoglobin (MetMb, brown color). Meat color is a critical component of purchasing decisions, and variability in color results in numerous factors, including species, age of the animal, breed, gender, feeding system and pre- and post-slaughter conditions.

The weight loss due to cooking was not influenced ( $\mathrm{P}>0.05$ ) by the inclusion of cactus pear in the diet (Table 3), and its mean value was $28.40 \%$. weight loss due to cooking is an important quality characteristic, as a measure of meat yield at the time of consumption (Pardi et al., 1993). The values observed in this study are similar to those reported by Bressan et al. (2001) for Santa Inês lambs (29.1\%) and below those reported by Costa et al. (2009), who observed a value of $27.68 \%$ for lambs of the same genotype. Johnson et al. (2005) observed values of weight loss due to cooking of 30.4 and $30.6 \%$ in the longissimus dorsi muscles of ram and ewe lambs with approximate live weights of 38 and $35 \mathrm{~kg}$, respectively.

The texture of the meat, as measured by shear force, did not vary $(\mathrm{P}>0.05)$ with the inclusion of cactus pear in the diet. This may be due to the fat score and solubility characteristics of the proteins present in this meat. According to the literature, sheep meat is tender when shear

Table 2 - Tissue component and leg muscularity index yields for different levels of replacement of corn by cactus pear

\begin{tabular}{|c|c|c|c|c|c|c|c|c|}
\hline \multirow[t]{2}{*}{ Variables } & \multicolumn{5}{|c|}{ Replacement level (\%) } & \multirow[t]{2}{*}{ CV (\%) } & \multirow[t]{2}{*}{ Regression equation } & \multirow[t]{2}{*}{$\mathrm{R}^{2}$} \\
\hline & 0 & 25 & 50 & 75 & 100 & & & \\
\hline Leg (kg) & 2.445 & 2.419 & 2.393 & 2.367 & 2.340 & 5.69 & $\mathrm{Y}=2.392 \mathrm{~ns}$ & - \\
\hline Muscle (\%) & 69.45 & 66.38 & 68.64 & 66.15 & 68.49 & 6.02 & $\mathrm{Y}=67.82 \mathrm{~ns}$ & - \\
\hline Fat $(\%)$ & 6.34 & 7.37 & 7.60 & 7.03 & 5.66 & 25.08 & $\mathrm{Y}=6.34+0.057 \times \mathrm{P}-0.00064 \times \mathrm{P}^{2}$ & 0.89 \\
\hline Bone (\%) & 19.94 & 20.68 & 19.02 & 18.23 & 21.08 & 13.62 & $\mathrm{Y}=19.79 \mathrm{~ns}$ & - \\
\hline Others (\%) & 4.68 & 3.91 & 4.54 & 5.30 & 4.73 & 36.33 & $\mathrm{Y}=4.63 \mathrm{~ns}$ & - \\
\hline $\mathrm{M}: \mathrm{B}$ & 3.56 & 3.28 & 3.64 & 3.66 & 3.31 & 14.92 & $\mathrm{Y}=3.49 \mathrm{~ns}$ & - \\
\hline $\mathrm{M}: \mathrm{F}$ & 11.35 & 9.67 & 9.31 & 10.25 & 12.51 & 23.23 & $\mathrm{Y}=11.35-0.09 \times \mathrm{P}+0.001 \times \mathrm{P}^{2}$ & 0.82 \\
\hline $\operatorname{MIP}(\mathrm{g} / \mathrm{cm})$ & 0.366 & 0.361 & 0.360 & 0.360 & 0.353 & 5.64 & $\mathrm{Y}=0.360 \mathrm{~ns}$ & - \\
\hline
\end{tabular}

ns - not significant; *(P<0.05); **(P<0.01); CV - coefficient of variation; M:B - musclue:bone ratio; M:F - muscle:fat ratio; MIP - muscularity index of the leg.

Table 3 - The effect of different levels of replacement of corn by cactus pear in the diet of Santa Inês sheep on the physical characteristics of the meat

\begin{tabular}{|c|c|c|c|c|c|c|c|}
\hline \multirow[t]{2}{*}{ Components } & \multicolumn{5}{|c|}{ Replacement level (\%) } & \multirow[t]{2}{*}{ Regression equation } & \multirow[t]{2}{*}{ CV (\%) } \\
\hline & 0 & 25 & 50 & 75 & 100 & & \\
\hline Initial pH & 6.71 & 6.69 & 6.53 & 6.90 & 6.82 & $\mathrm{Y}=6.73 \mathrm{~ns}$ & 4.6 \\
\hline $\mathrm{L}$ & 19.53 & 19.91 & 16.74 & 20.76 & 19.97 & $\mathrm{Y}=19.38 \mathrm{~ns}$ & 20.92 \\
\hline $\mathrm{a}$ & 4.49 & 5.03 & 4.17 & 5.42 & 5.16 & $\mathrm{Y}=4.85 \mathrm{~ns}$ & 33.65 \\
\hline $\mathrm{b}$ & 19.71 & 20.80 & 21.11 & 19.91 & 20.04 & $\mathrm{Y}=20.31 \mathrm{~ns}$ & 9.01 \\
\hline Final pH & 5.63 & 5.67 & 5.74 & 5.71 & 5.67 & $\mathrm{Y}=5.68 \mathrm{~ns}$ & 6.22 \\
\hline WLC & 27.70 & 27.66 & 29.22 & 29.45 & 29.19 & $\mathrm{Y}=28.40 \mathrm{~ns}$ & 10.22 \\
\hline SF & 2.54 & 2.40 & 2.40 & 2.15 & 2.85 & $\mathrm{Y}=2.50 \mathrm{~ns}$ & 18.93 \\
\hline
\end{tabular}

ns $(\mathrm{P}>0.05)$.

L, a and b - intensity of luminosity, red color and yellow color, respectively; WLC - weight loss due to cooking; SF - shear force; CV - coefficient of variation. 
force is below $8 \mathrm{Kgf} / \mathrm{cm}^{2}$, acceptable when it falls between 8 and $11 \mathrm{Kgf} / \mathrm{cm}^{2}$ and hard if the value exceeds $11 \mathrm{Kgf} / \mathrm{cm}^{2}$ (Bickerstaffe et al., 1997). The mean shear force value of $2.5 \mathrm{Kgf} / \mathrm{cm}^{2}$ in this study indicates that the sheep meat assessed can be classified as very tender.

The inclusion of cactus pear in the diet of sheep did not influence $(\mathrm{P}>0.05)$ moisture, ash or protein percentages of the longissimus dorsi muscle (Table 4). In sheep meat, the proximate composition varies with animal age, slaughter weight, fat content and nature of the diet, with mean values of $75 \%$ moisture, $2.5 \%$ fat and $1.2 \%$ ash (Ortiz et al., 2005). The values observed in this study are similar to those reported by Costa et al. (2009), who observed mean values of 22.93, $0.89,74.41$ and $2.22 \%$ for protein, ash, moisture and lipids, respectively, and indicate the meat had good nutritional quality. The protein values observed were also similar to those reported by Madruga et al. (2005) and Santos et al. (2008), who obtained values ranging from 19.08 and $21.06 \%$ for sheep of the same genotype.

The lipid content showed a decreasing linear effect $(\mathrm{P}<0.05)$ and may have reflected in decreased metabolizable energy as the corn replacement level by cactus pear increased. Replacing up to $100 \%$ of corn by cactus pear has desirable effects, as it produces legs with a reduced fat yield and similar muscle yield to those found in animals fed corn (Brito Neto et al., 2007; Sousa et al., 2007). Madruga et al., (2005) also reported reductions in fat content, with mean values of $2.74 \%$, when cactus pear was included in the diet of Santa Inês lambs.

The sensory analysis of the meat indicates that no characteristics were influenced $(\mathrm{P}>0.05)$ by the inclusion of cactus pear in the diet (Table 5; Figure 1). The characteristics of succulence, taste and overall acceptability were 5.38,
4.17 and 6.29, respectively. These organoleptic characteristics are associated with meat tenderness and determine the pleasant or unpleasant feeling that leads to acceptance or refusal by the consumer.

A mean value of 3.17 was observed for meat hardness, reflecting good pre-slaughter management conditions. Meat hardness is directly related to pre-slaughter factors, including pre-slaughter stress, and post-mortem factors that alter myofibrillar structures. The post-mortem glycolysis rate, for example, is determined by several factors, including the final $\mathrm{pH}$ and the process of maturation. The sensory analysis results show that the meat in this study could be classified as tender and succulent and had a characteristic taste of sheep meat and good overall acceptability.

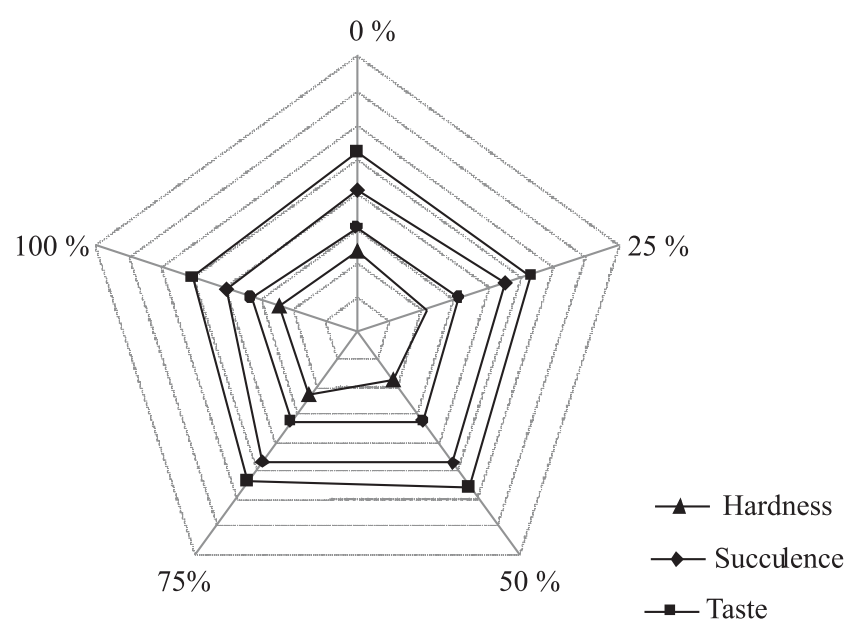

Figure 1 - Sensory characteristics of the meat of Santa Ines sheep fed diets with different levels of replacement of corn by cactus pear.

Table 4 - Chemical composition of Santa Inês sheep meat for different levels of replacement of corn by cactus pear

\begin{tabular}{|c|c|c|c|c|c|c|c|c|}
\hline \multirow[t]{2}{*}{ Composition (\%) } & \multicolumn{5}{|c|}{ Replacement level (\%) } & \multirow[t]{2}{*}{ CV (\%) } & \multirow[t]{2}{*}{ Regression equation } & \multirow[t]{2}{*}{$\mathrm{R}^{2}$} \\
\hline & 0 & 25 & 50 & 75 & 100 & & & \\
\hline Moisture & 75.49 & 75.59 & 75.68 & 75.32 & 75.83 & 1.14 & $\mathrm{Y}=75.59 \mathrm{~ns}$ & - \\
\hline Lipids & 2.85 & 2.71 & 2.57 & 2.42 & 2.28 & 25.27 & $\mathrm{Y}=2.852-0.005724 * \mathrm{P}$ & 0.61 \\
\hline Protein & 20.74 & 20.55 & 20.68 & 20.83 & 21.03 & 3.72 & $\mathrm{Y}=20.77 \mathrm{~ns}$ & - \\
\hline Ash & 1.01 & 1.00 & 1.01 & 1.05 & 1.01 & 6.16 & $\mathrm{Y}=1.02 \mathrm{~ns}$ & - \\
\hline
\end{tabular}

ns $(\mathrm{P}>0.05) ; *(\mathrm{P}<0.05)$.

$C V$ - coefficient of variation; $R^{2}$ - coefficient of determination.

Table 5 - Sensory characteristics of the meat from sheep fed diets with different levels of replacement of corn by cactus pear

\begin{tabular}{lccccccc}
\hline & \multicolumn{4}{c}{ Replacement level (\%) } & Regression equation & CV (\%) \\
\cline { 2 - 5 } & 0 & 25 & 50 & 75 & 100 & \\
\hline Hardness & 3.31 & 3.12 & 2.74 & 3.30 & 3.38 & $\mathrm{Y}=3.17 \mathrm{~ns}$ & 34.82 \\
Succulence & 5.14 & 5.55 & 5.68 & 5.61 & 4.93 & $\mathrm{Y}=5.38 \mathrm{~ns}$ & 32.13 \\
Taste & 4.03 & 4.12 & 4.22 & 4.25 & 4.22 & $\mathrm{Y}=4.17 \mathrm{~ns}$ & 47.1 \\
Overall acceptability & 6.21 & 6.31 & 6.59 & 6.37 & 5.98 & $\mathrm{Y}=6.29 \mathrm{~ns}$ & 23.01 \\
\hline
\end{tabular}

$\mathrm{CV}$ - coefficient of variation. 


\section{Conclusions}

Cactus pear can replace up to $100 \%$ of corn in the diets of Santa Inês sheep raised in confinement and produces a decrease in the percentage of lipids. These changes occur without compromising the tissue component yield of the leg or altering the physical or sensory characteristics of the meat.

\section{References}

AMARINE, M.A.; PANGBORN, M.R.; ROESSLER, E.B. Principles of sensory evaluation off. New York: Academic Press, 1965. $602 p$.

ASSOCIATION OF ANALITICAL CHEMISTS - AOAC. Official methods of analysis of AOAC International. 19.ed. Washington, D.C.: AOAC International, 2000. 1219p.

BICKERSTAFFE, R.; LE COUTEUR, C.E.; MORTON, J.D. Consistency of tenderness in New Zealand retail meat. In: International Congress of Meat Science Technology, v.43, p.196-197, 1997.

BRESSAN, M.C.; PRADO, O.V.; PÉREZ, J.R.O. et al. Effect of the slaughter weight on the physicalchemical characteristic of bergamacia and santa inês lambs meat. Science and Food Technology, v.21, p.293-303, 2001.

BRITO NETO, P.B.; SANTOS, J.R.S.; CÉZAR, M.F. et al. Rendimento dos constituintes teciduais da perna de ovinos Santa Inês submetidos a diferentes níveis de substituição do farelo de milho por farelo de palma na ração de terminação. In: SIMPÓSIO INTERNACIONAL SOBRE CAPRINOS E OVINOS DE CORTE, 3., 2007, João Pessoa. Anais... João Pessoa, 2007. (CD-ROM).

COSTA, R.G.; BATISTA, A.S.M.; MADRUGA, M.S. et al. Physical and chemical characterization of lamb meat from different genotypes submitted to diet with different fibre contents. Small Ruminant Research, v.81, p.29-34, 2009.

DABÉS, A.C. Propriedades da carne fresca. Revista Nacional da Carne, v.25, n.288, p.32-40, 2001.

DEVINE, C.E.; GRAAFHUIS, A.E.; MUIR, P.D. et al. The effect of growth rate and ultimate $\mathrm{pH}$ on meat quality in lambs. Meat Science, v.35, p.63-77, 1993.

DUCKETT, S.K.; KLEIN, T.A.; DODSON, M.V. et al. Tenderness of normal and callipyge lamb aged fresh or after freezing. Meat Science, v.49, p.19-26, 1998a.

DUCKETT, S.K.; KLEIN, T.A.; LECKIE, R.K. et al. Effect of freezing on calpastatin activity and tenderness of callipyge lamb. Journal of Animal Science, v.76, p.1869-1874, 1998b.

FERNANDES, M.A.M.; MONTEIRO, A.L.G.; POLI, C.H.E.C. et al. Composição tecidual da carcaça e perfil de ácidos graxos da carne de cordeiros terminados a pasto ou em confinamento. Revista Brasileira de Zootecnia, v.39, n.7, p.1600-1609, 2010.

FOLCH, J.; LESS, M.; STANLEY, S. A simple method for the isolation and purification of total lipids from animal tissues. Journal of Biological Chemistry, v.226, p.497-509, 1957.

HOFFMAN, L.C.; MULLER, M.; CLOETE, S.W.P. et al. Comparison of six crossbred lamb types: sensory, physical and nutritional meat quality characteristics. Meat Science, v.65, p.1265-1274, 2003.

HUIDOBRO, F.R.; CAÑEQUE, V. Produccion de carne en corderos de raza Manchega. III. Composição tisular de las canales y de las piezas. Revista Producción Sanidad Animal, v.9, p.57-69, 1994.

JOHNSON, P.L.; PURCHAS, R.W.; MCEWAN, J.C. et al. Carcass composition and meat quality differences between pasturereared ewe and ram lambs. Meat Science, v.71, p.383-391, 2005.

LARMOND, E. Laboratory methods for evaluation of foods. Ottawa: Food Research Institute/Canada Department of Agriculture, 1979. 432p.
MADRUGA, M.S.; SOUZA, W.H.; ROSALES, M.D.R. et al. Qualidade da carne de cordeiros Santa Inês terminados com diferentes dietas. Revista Brasileira de Zootecnia, v.34, p.309-315, 2005.

MADRUGA, M.S.; SOUZA, J.G.; NARAIN, N. Castration and slaughter age effects on fat components of "Mestiço" goat meat. Small Ruminant Research, v.42, p.77-82, 2001.

MADRUGA, M.S.; ARRUDA, S.G.B.; NARAIN, N. et al. Castration and slaughter age effects on panel assessment and aroma compounds of the "mestiço" goat meat. Meat Science, v.56, p.117-125, 2000 .

NATIONAL RESEARCH COUNCIL - NRC. Nutrient requirements of sheep. Washington, D.C.: National Academy Press, 1985. 99p.

ORTIZ, J.S.; COSTA, C.; GARCIA, C.A. et al. Medidas objetivas das carcaças e composição química do lombo de cordeiros alimentados e terminados com três níveis de proteína bruta em creep feeding. Revista Brasileira de Zootecnia, v.34, p.2382-2389, 2005.

PARDI, M.C.; SANTOS, I.F.; SOUZA, E.R. et al. Ciência, higiene e tecnologia da carne: tecnologia da sua obtenção e transformação. Goiânia: Centro Editorial e Gráfico Universidade de Goiás, 1993. 586p.

PURCHAS, R.W.; DAVIES, A.S.; ABDULLAH, A.Y. An objective measure of muscularity: changes with animal growth and differences between genetic lines of Southdown sheep. Meat Science, v.30, p.81-94, 1991.

RETAMAL, N.; DURAN, J.M.; FERNANDEZ, J. Seasonal variations of chemical composition in pickly pear (Opuntia ficus-indica (L.) Miller). Journal Science Food Agriculture, v.38, n.4, p.303-311, 1987.

SANTOS, C.L.; PEREZ, J.R.O.; CRUZ, C.A.C. et al. Análise centesimal dos cortes da carcaça de cordeiros Santa Inês e Bergamácia. Ciência e Tecnologia de Alimentos, v.28, p.51-59, 2008.

SAÑUDO, C.; SANTOLARIA, P.; SIERRA, I. Sensory meat characteristics from light lamb carcasses. In: INTERNACIONAL CONGRESS OF MEAT SCIENCE AND TECHNOLOGY, Clermont - Ferrant, France. Proceedings... Ferrant: Clermont, 1992. p.277-280.

SCHÖNFELDT, H.C.; GIBSON, N. Changes in the nutrient quality of meat in an obesity context. Meat Science, v.80, p.20-27, 2008.

SILVA SOBRINHO, A.G.; PURCHAS, R.W.; KADIM, I.T. et al. Características de qualidade da carne de ovinos de diferentes genótipos e idades ao abate. Revista Brasileira de Zootecnia, v.34, p.1070-1078, 2005.

SILVA SOBRINHO, A.G. Body composition and characteristics of carcass from lambs of different genotypes and ages at slaughter. Palmerston North: Massey University, 1999. 54p. Report (Post Doctorate in Sheep Meat Production).

SOUSA, D.O.; SANTOS, J.R.S.; CÉZAR, M.F. et al. Efeito da substituição do farelo de milho por farelo de palma sobre o peso dos constituintes teciduais da perna de ovinos Santa Inês em confinamento. In: SIMPÓSIO INTERNACIONAL SOBRE CAPRINOS E OVINOS DE CORTE, 3., João Pessoa. Anais... João Pessoa, 2007. (CD-ROM).

TEIXEIRA, A.; BATISTA, S.; DELFA, R. et al. Lamb meat quality of two breeds with protected origin designation. Influence of breed, sex and live weight. Meat Science, v.71, p.530-536, 2005.

WANDERLEY, W.L.; FERREIRA, M.A.; ANDRADE, D.K.B. et al. Palma forrageira (Opuntia fícus-indica Mill) em substituição à silagem de sorgo (Sorgum bicolor, (L.) Moench) na alimentação de vacas leiteiras. Revista Brasileira de Zootecnia, v.31, p.273-281, 2002.

WEISS, W.P. Energy prediction equations for ruminant feeds. In: CORNELL NUTRITION CONFERENCE FEED MANUFACTURES, 61., 1999, Ithaca. Proceedings... Ithaca: Cornell University, 1999. p.176-185 